\title{
A RESPONSE TO "MILANKOVITCH THEORY VIEWED FROM DEVILS HOLE" BY J. IMBRIE, A. C. MIX AND D. G. MARTINSON
}

By Isaac J. Winograd and Jurate Maciunas Landwehr

\section{U.S. GEOLOGICAL SURVEY \\ Open-File Report 93-357}

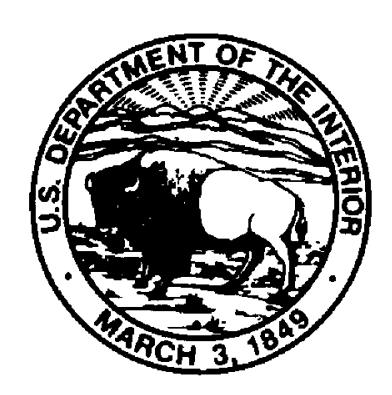

Reston, Virginia 


\title{
U. S. DEPARTMENT OF THE INTERIOR BRUCE BABBITT, Secretary
}

\author{
U. S. GEOLOGICAL SURVEY \\ Robert M. Hirsch, Acting Director
}

For additional information write to:

Chief, Paleoclimatology / Aquifer

Geochemistry Project

U.S. Geological Survey

MS 432 - National Center

Reston, Virginia 22092
Copies of this report can be purchased from:

U.S. Geological Survey

Books and Open-File Reports Section

Federal Center, Box 25286

Denver, Colorado 89225 


\section{CONTENTS}

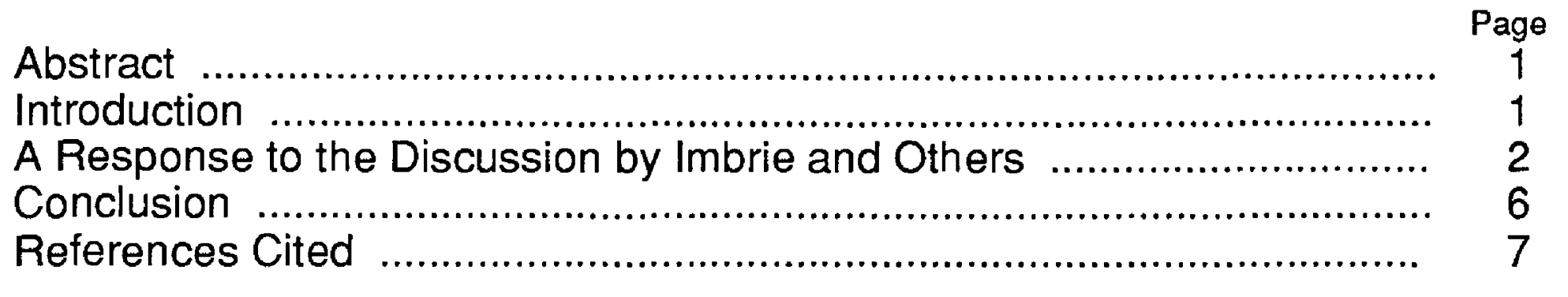

\section{ILLUSTRATIONS}

Figure 1. Sedimentation rates in core RC11-120 using SPECMAP chronology. 


\title{
A Response to "Milankovitch Theory Viewed from Devils Hole" by J. Imbrie, A. C. Mix, and D. G. Martinson \\ By Isaac J. Winograd and Jurate Maciunas Landwehr
}

\begin{abstract}
The detailed and well-dated 500,000 -year record of $\delta^{18} \mathrm{O}$ variations found in vein calcite core DH-11 taken from Devils Hole in Nevada (Winograd and others, 1992) provides several challenges to the Milankovitch theory for the occurrence of Quaternary glaciations. A recent discussion paper (Imbrie and others, 1993) has dismissed the relevance of this well-dated core for determining the timing of global climatic fluctuations and, moreover, asserts that the Devils Hole record provides support for the Milankovitch theory. Upon analysis of the arguments found in this discussion, we find nothing to dissuade us from the original conclusion that the Devils Hole chronology does present a serious challenge to the Milankovitch theory.
\end{abstract}

\section{INTRODUCTION}

The trace of $\delta^{18} \mathrm{O}$ variations in vein calcite core $\mathrm{DH}-11$, taken from Devils Hole in Nevada (Winograd and others, 1992), provides a detailed 500,000-year paleoclimate record (Ludwig and others, 1992; Edwards and Gallup, 1993; Ludwig and others, 1993a; Shackleton, 1993; Ludwig and others, 1993b), arguably the best-dated paleo-climate record available today. Indeed, Broecker (1992) has stated that "...the new Devils Hole chronology is more firm than any other available isotopic age in this range. Nowhere else has a high degree of concordance between ${ }^{234} \mathrm{U}-238 \mathrm{U}$ and ${ }^{230} \mathrm{Th}-234 \mathrm{U}$ ages been achieved. No other archive is better preserved. No other record has so many stratigraphically ordered radiometric ages."

Broecker (1992) concurred with the conclusion of Winograd and others (1992) that the timing of the ices ages as determined in this paleoclimate record cannot be reconciled with the Milankovitch theory that ice ages have been driven by periodic variations in the Earth's orbit. In addition to the problem of timing, Winograd and others (1992) pointed out that the Devils Hole (hereafter DH) record offers three other challenges to the Milankovitch theory: (1) the duration of the interglacial climates is closer to $20 \mathrm{kyr}$ than to the predicted $10 \mathrm{kyr}$ duration; (2) the length of glacial cycles increases steadily as one comes forward in time which is inconsistent with the assumption of a quasi-100 kyr cycle; and (3) a well-developed glacial cycle occurs in the period $450-350 \mathrm{ka}$ at a time when the insolation theory indicates none should occur. 
A discussion of the $\mathrm{DH} \delta^{18} \mathrm{O}$ record by J. Imbrie, A. C. Mix, and D. G. Martinson (1993), hereafter referred to as IMM, has recently appeared in the literature. This discussion does not address the four challenges posed to the Milankovitch theory by the $\mathrm{DH}$ chronology. Rather, it denies the relevance of the $\mathrm{DH}$ record in the determination of the timing of global climatic events, and asserts that the DH record provides strong support for the Milankovitch theory. Upon analysis of the arguments made by IMM, we find nothing to dissuade us from the original conclusion that the DH chronology does present a serious challenge to the Milankovitch theory.

Our analysis has not been appeared in the public literature to date: the journal that printed the IMM discussion has chosen not to publish our response on the grounds that it would be of interest only to specialists working in this field.

Nonetheless, we continue to receive inquiries from members of the scientific community regarding the issues raised in the discussion by IMM and requests for our written response to these issues. Because the usual means of responding in the open literature has not been available to us, and because we continue to receive inquiries regarding IMM's commentary, we now make our analysis of their discussion available for public debate.

\section{A RESPONSE TO THE DISCUSSION BY IMBRIE AND OTHERS}

\section{J. Imbrie, A. C. Mix, and D. G. Martinson make three points in their recently} published discussion (1993). They argue first that applying the DH paleotemperature chronology to ocean cores results in implausible changes in sedimentation rate and thereby reaffirm the accuracy of the marine (SPECMAP) ice-volume chronology. Next, they claim that a convincing test of the Milankovitch hypothesis in the time domain is not possible without detailed global and local process models. Finally, they argue, from frequency domain (i.e., spectral analysis) considerations, that the $\mathrm{DH}$ record is "not inconsistent with modern versions of the Milankovitch theory" and indeed lends strong support in its favor. We explain below why we disagree with these arguments.

The overall similarity between the $\delta^{18} \mathrm{O}$ chronologies for DH and SPECMAP is remarkable. (IMM show a linear correlation of 0.85.) However, the two chronologies differ in the timing and duration of certain isotopic stages, notably during the 6/5 transition, key to the Milankovitch theory in its modern form (Imbrie, 1987; Imbrie, 1992; Ruddiman and Wright, 1987). Application of these two chronologies to the same record will therefore consistently result in different sedimentation rate estimates around such periods. IMM apply the $\mathrm{DH}$ chronology to four selected marine cores and obtain sedimentation rates that vary by a factor of 5 or 6 during the interval $\sim 125$ to $200 \mathrm{ka}$ (their isotope "stage 6 anomaly"). Noting generally smaller changes in sedimentation rate during isotope stages 1 and 2 (i.e., the past $\sim 30 \mathrm{kyr}$ ), they infer that changes by a factor of 5 or 6 are "physically implausible" for isotope stage 6 . They conclude that the DH chronology, though assumed by them to be correctly dated, cannot be applied to marine cores, and reaffirm that the SPECMAP chronology must be 
accurate. But we cannot find support in IMM's own work for either the inference or the conclusion.

IMM's Figure 3 suggests relatively constant sedimentation rates during isotope stage 6 when the SPECMAP chronology is applied, but Figure 7 of an earlier paper by IMM and others (Imbrie and others, 1984) shows the variation to be more extreme in these and other cores. Indeed, based on the age-depth data in Table 6 of that earlier paper by IMM with other colleagues (Imbrie and others, 1984), sedimentation rates varying up to a factor of 12 are obtained for core RC11-120 in the interval $\sim 125$ to $\sim 200$ ka when the SPECMAP chronology is adopted. We show this in our Figure 1, given herein, which is just an expanded scale plot for core RC11-120.1 Thus, by IMM's own criteria, the SPECMAP chronology also yields "physically implausible" sedimentation rates and should not be applied to this marine core.

Additionally, IMM themselves report a sedimentation rate change across the isotope stage 2/1 transition of "... a factor of 5 lower near RC11-120...", suggesting that such changes have been measured in cores where radiometric dating is possible. We note that for the period beyond $\sim 40 \mathrm{ka}$, and extending to the Bruhnes-Matuyama paleomagnetic reversal (about $\sim 780 \mathrm{ka}$ ), there are no radiometric dates available with which to measure and compare sedimentation rates in any of IMM's cores (Imbrie and others, 1984). Thus, IMM's indirect sedimentation-rate argument has not demonstrated the accuracy of the SPECMAP chronology .

IMM assert that before the validity of the Milankovitch hypothesis can be addressed convincingly in the time domain, two detailed models are necessary -one of "processes governing the response of the climate system to Milankovitch forcing" and a second "that will isolate the local temperature component of the $\mathrm{DH}-11$ record". Their first required model is formidable: it effectively precludes "time-domain" testing of this hypothesis in the immediate future. Yet, paleoclimatologists have been claiming "time-domain" support for the Milankovitch hypothesis for almost 25 years. Specifically, the major peak in highlatitude Northern Hemisphere insolation at $\sim 128 \mathrm{ka}$ has been repeatedly cited as the pacemaker for the penultimate deglaciation, i.e., termination II (Imbrie, 1987; Imbrie, 1992; Ruddiman and Wright, 1987). IMM themselves cite interglacial sea-level high stands (based on coral dates) between 122-126 ka, a time that appropriately followed the $128 \mathrm{ka}$ insolation peak. Thus, the challenge in the time-domain posed by the $\mathrm{DH}-11$ chronology to the Milankovitch hypothesis as

\footnotetext{
1 Prell and others $(1986$, p.153) report that "...the core pipes were decoupled at approximately $570 \mathrm{~cm}$ " in core RC11-120, while Martinson and others (1987, p.11) report that this decoupling occurs at a depth of $600 \mathrm{~cm}$. Might the sudden increases in sedimentation rate shown in our Figure 1 at depths of about $600 \mathrm{~cm}$ and about $490 \mathrm{~cm}$ reflect extrusion (or stretching) of core RC11-120 following pipe decoupling? The increase in sedimentation rate, from 1 to $4 \mathrm{~cm}$ per $10^{3}$ years, at a depth of about $600 \mathrm{~cm}$ (Figure 1) might possibly be due to pipe decoupling. However, the major feature of Figure 1 , the $12 \mathrm{~cm}$ per $10^{3}$ year sedimentation rate in the interval $490-550 \mathrm{~cm}$ cannot be attributed to core stretching; this interval $(490-550 \mathrm{~cm})$ is separated from the possibly stretched deeper interval (below a depth of $600 \mathrm{~cm}$ ) by $50 \mathrm{~cm}$ of core with average sedimentation rate -- i.e. by apparently unstretched core.
} 


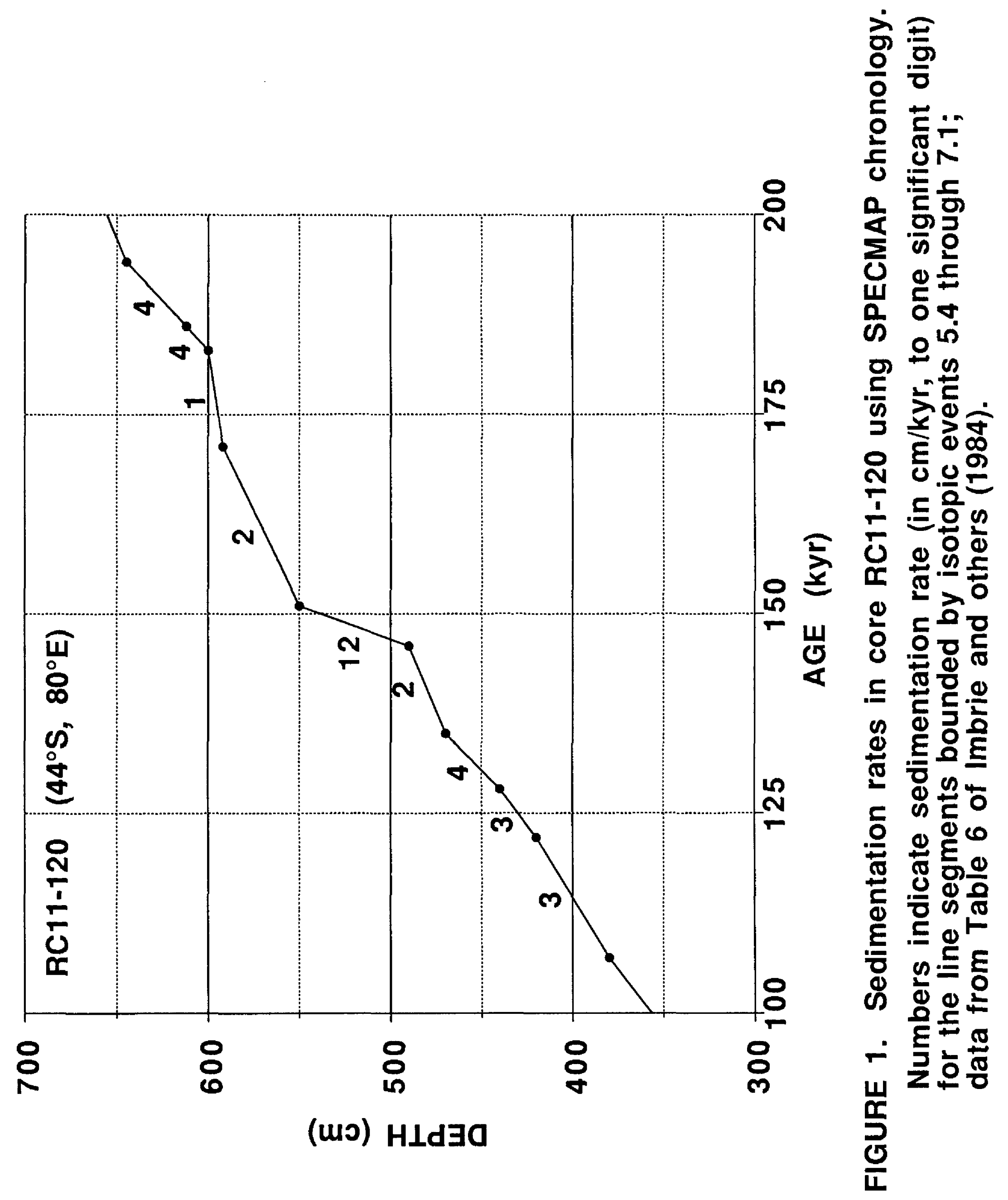


presented by Winograd and others (1992) is in keeping with considerable precedent, and IMM's categorical dismissal of such testing is also inconsistent with their own work.

The second model that IMM require is one "that will isolate the local temperature component of the DH-11 record" from variations in the isotopic content of moisture sources and varying air-parcel trajectories. We (Winograd and others, 1988 ) and Grootes (1993) have discussed these concerns. When the proposed moisture-source corrections have been applied (Grootes, 1993) to the DH chronology, they increase the amplitude of $\delta^{18} \mathrm{O}$ variations but do not change our $140 \mathrm{ka}$ age for termination II, the isotope stage 6/5 transition (Winograd and others, 1992). This age -- which precedes the major Northern Hemisphere $128 \mathrm{ka}$ insolation peak by at least $12 \mathrm{kyr}$-- thus remains a major "time domain" challenge to the Milankovitch hypothesis. Similarly, such corrections do not change the DH age $(\sim 132 \mathrm{ka})$ for the attainment of the last interglacial climate at $\sim 4 \mathrm{kyr}$ prior to the insolation peak. The same age for this event has been reported in studies of high resolution marine sediments (Sarnthein and Tiedemann, 1990), of uranium-series-dated sea-level high stands in the Bahamas (Chen and others, 1991) and Australia (Zhu and others, 1993) and of ice cores from Summit, Greenland (Dansgaard and others, 1993) and from Vostok, Antarctica (Jouzel and others, 1993). In contrast, SPECMAP indicates attainment of interglacial climate $\sim 4 \mathrm{kyr}$ after the $128 \mathrm{ka}$ insolation peak.

Finally, IMM contend that the presence of orbitally consistent spectral frequency peaks (i.e. the 42 and $23 \mathrm{kyr}$ cycles) in the Devils Hole $\delta^{18} \mathrm{O}$ time series support "the Milankovitch theory that the Earth's glacial-interglacial cycles are driven by orbital variations" (Imbrie and others, 1993). We reiterate what was stated by Winograd and others (1992), albeit succinctly. Such cycles -- assumed to be caused by orbitally-controlled variations in insolation -- have been documented in marine and lacustrine sediments of Triassic and late Cretaceous (Upper Albian through Maastrichtian) age, times that lacked Northern and Southern Hemisphere ice sheets (Herbert and Fischer, 1986; Olsen, 1986; Frakes and others, 1992, chapts. 6, 8, and 11). In addition, Joyce and others (1990) report such cycles in marine sediments deposited during the middle Pliocene ( 4.0 to $3.2 \mathrm{ka}$ ), a period of exceptional global warmth, when sea level was as much as $30 \mathrm{~m}$ above modern (Krantz, 1991). Milankovitch himself (1941, p. 481) explicitly recognized that sedimentary and insolation cycles occurred throughout geologic time, and that the presence of such cycles does not constitute a sufficient condition for the origin of Northern Hemisphere Quaternary glaciation. 


\section{CONCLUSION}

Imbrie, Mix and Martinson's (1993) indirect sedimentation-rate argument for the accuracy of the radiometrically undated SPECMAP chronology is unconvincing. Their categorical dismissal of "time domain" testing of the Milankovitch hypothesis is inconsistent with their own prior work and that of other paleoclimatologists. "Frequency domain" testing does not provide strong support for their conclusion that the Devils Hole record is consistent with the Milankovitch hypothesis for the origin of Quaternary glaciation of the Northern Hemisphere. 


\section{REFERENCES CITED}

Broecker, W. S., 1992, Upset for Milankovitch theory: Nature, v. 359, p. 779-780.

Chen, J.H., Curran, H. A., White, B., and Wasserburg, G. J., 1991, Precise chronology of the last interglacial period: $234 \mathrm{U}-230 \mathrm{Th}$ data from fossil coral reefs in the Bahamas: Geological Society of America Bulletin, $v 103$, p. 82-97.

Dansgaard, W., Johnsen, S. J., Clausen, H. B., Dahl-Jensen, D., Gundestrup, N. S., Hammer, C. U., Hvidberg, C. S., Steffensen, J. P., Sveinbjornsdotter, A. E., Jouzel, J., and Bond, G., 1993, Evidence for general instability of past climate from a 250-kyr ice-core record: Nature, v 364, p. 218-220.

Edwards, R. L., and Gallup, C. D., 1993, Dating of the Devils Hole calcite vein: Science, v. 259, p. 1626.

Frakes, L. A., Francis, J. E., and Syktus, J. I., 1992, Climate Modes of the Phanerozoic, Cambridge, Cambridge Univ. Press, 274 pp.

Grootes, P.M., 1993, Interpreting continental oxygen isotope records, in Swart, P. K., Lohmann, K. C., McKenzie, J., and Savin, S., Climate Change in Continental Isotopic Records, Geophysical Monograph 78: Washington, D. C., American Geophysical Union, p. 37-46.

Herbert, T.D. and Fischer, A.G., 1986, Milankovitch climatic origin of midCretaceous black shale rhythms in central Italy: Nature, v. 321, p. 739-743.

Imbrie, J., 1992, Editorial : A good year for Milankovitch: Paleoceanography, v. 7, p. 687-690.

Imbrie, J., 1987, Abrupt terminations of late Pleistocene ice ages : a simple Milankovitch explanation, in Berger, W. H. and Labeyrie, L. D., Abrupt Climate Change: Dordrecht, D. Reidel Publishing Company, p. 365-367.

Imbrie, J., Hays, J. D., Martinson, D. G., McIntyre, A., Mix, A. C., Morley, J. J., Pisias, N. G., Prell, W. L., and Shackleton, N. J., 1984, The orbital theory of Pleistocene climate: support from a revised chronology of the marine $\delta^{18} \mathrm{O}$ record, in Berger, A., et al., Milankovitch and Climate: Dordrecht, D. Reidel Publishing Company, p. 269-305.

Imbrie, J., Mix, A. C., and Martinson, D. G., 1993, Milankovitch theory viewed from Devils Hole: Nature, v. 363, p. 531-533.

Jouzel, J., Barkov, N. I., Barnola, J. M., Bender, M., Chappelaz, J., Genthon, C., Kotlyakov, V. M., Lipenkov, V., Lorius, C., Petit, J. R., Raynaud, D., Raisbeck, G., Ritz, C., Sowers, T., Stievenard, M., Yiou, F., and Yiou, P., 
1993, Extending the Vostok ice-core record of paleoclimate to the penultimate glacial period: Nature, v. 364, p. 407-412.

Joyce, J. E., Tjalsma, L. R. C., and Prutzman, J. M., 1990, High-resolution planktic stable isotope record and spectral analysis for the last 5.35 M.Y.: ocean drilling program site 625 northeast Gulf of Mexico: Paleoceanography, v. 5, pp. 507-529.

Krantz, D. E., 1991, A chronology of Pliocene sea-level fluctuations: the U. S. Middle Atlantic Coastal Plain record: Quaternary Science Reviews, v. 10, p. 163-174.

Ludwig, K. R., Simmons, K. R., Szabo, B. J., Winograd, I. J., Landwehr, J. M., Riggs, A. C., and Hoffman, R. J., 1992, Mass-Spectrometric 230Th-234U238U Dating of the Devils Hole Calcite Vein: Science, V. 258, p. 284-287.

Ludwig, K. R., Simmons, K. R., Winograd, I. J., Szabo, B. J., and Riggs, A. C., 1993a, Response to Edwards and Gallup: Science, v. 259, p. 1626-1627.

Ludwig, K. R., Simmons, K. R., Winograd, I. J., Szabo, B. J., Landwehr, J. M., and Riggs, A. C., 1993b, Response to Shackleton: Nature, v. 362, p. 596.

Martinson, D. G., Pisias, N. G., Hays, J. D., Imbrie, J., Moore, T. C., Jr., and Shackleton, N. J., 1987, Age dating and the orbital theory of the ice ages: development of a high-resolution 0 to 300,000 -year chronostratigraphy: Quaternary Research, v. 27, p. 1-29.

Milankovitch, M., 1941, Canon of Insolation and the Ice-Age Problem, Royal Serbian Academy Special Publications, Vol. 132, Section of Mathematical and Natural Sciences, Vol. 33; translated from German by B. Benny and I. Meroz, 1969, Israel Program for Scientific Translations; available from U.S. Department of Commerce, Clearinghouse for Federal Scientific and Technical Information, Springfield, Virginia.

Olsen, P.E., 1986, 40-million-year lake record of early Mesozoic orbital climatic forcing: Science, v. 234, p. 842-848.

Prell, W. L., Imbrie, J., Martinson, D. G., Morley, J. J., Pisias, N. G., Shackleton, N. J., and Streeter, J. F., 1986, Graphic correlation of oxygen isotope stratigraphy application to the late Quaternary: Paleoceanography, v. 1, p. 137-162.

Ruddiman, W. F. and Wright, H. E., Jr., 1987, Introduction, in Ruddiman, W. F., and Wright, $H$. E., Jr., North America and Adjacent Oceans During the Last Deglaciation, The Geology of North America, K-3: Boulder, Geological Society of America, p. 1-12.

Sarnthein, M. and Tiedemann, R., 1990, Younger Dryas-style cooling events at glacial terminations I-VI at ODP Site 658: associated benthic $\delta^{13} \mathrm{C}$ 
anomalies constrain meltwater hypothesis: Paleoceanography, v. 5, p. 1041-1055.

Shackleton, N. J., 1993, Last interglacial in Devils Hole: Nature, v. 362, p. 596.

Winograd, I. J., Szabo, B. J., Coplen, T. B., and Riggs, A. C.,1988, A 250,000year climatic record from Great Basin vein calcite: implications for Milankovitch theory : Science, v. 242, p. 1275-1280.

Winograd, I. J., Coplen, T. B., Landwehr, J. M., Riggs, A. C., Ludwig, K. R., Szabo, B. J., Kolesar, P. T., and Revesz, K. M., 1992, Continuous 500,000 -year climate record from vein calcite in Devils Hole, Nevada:

Science, v. 258, p. 255-260.

Zhu, Z. R., Wyrwoll, K.-H., Collins, L. B., Chen, J. H., Wasserburg, G. J., and Eisenhauer, A., 1993, High-precision U-series dating of Last Interglacial events by mass spectrometry: Houtman Abrolhos Islands, western Australia: Earth and Planetary Science Letters, v. 118, p. 281-293. 